\title{
DIK ROTH
}

\section{Lebensraum in Luwu Emergent identity, migration and access to land}

\author{
Rantepao, Makale and Poso \\ Rongkong, Mamasa and Galumpang \\ All will be united into one \\ The Toraja people will be unified \\ Let us all become one \\ Create a Greater Toraja \\ All agreeing, all becoming one \\ To build a Greater Toraja \\ (Toraja Raya song; see map) ${ }^{1}$
}

\section{Introduction}

The downfall of the Soeharto regime has radically changed power relations between centre and region in Indonesia. Decentralization and administrative fragmentation (pemekaran), based on Government Regulation 129/2000, have created new opportunities for political actors at all levels. As a result, from the late 1990s, regional autonomy movements have mushroomed. ${ }^{2}$ These changes in administrative structures often entail a radical reshuffle of relationships, patterns of control over resources, identities, territories and boundaries. Therefore, such changes can only be understood against the background of their specific historical contexts, paying attention not only to the changes but also to the 'changing continuities' (Schulte-Nordholt 2003) behind such changes.

1 Greater Toraja (Dutch Grooter Toradja) remained popular until the 1960s, when hopes for Greater Toraja were lost. Interviews on issues discussed in this article were held in Sulawesi and Jakarta in 1990-1992, 1995-1997, 1999 and 2004. References in the footnotes to interviews give name, place and year. In case of sensitive issues, no sources are given.

2 Tempo, 28-4-2001; www.gtzsfdm.or.id/documents/dec_ind/newsletter/Newsletter6.pdf; www.bps.go.id/mstkab/kab-2004-UU.pdf (accessed 15-9-2005).

DIK ROTH is a social anthropologist currently working as a lecturer and researcher at the Law and Governance Group of Wageningen University, Wageningen, the Netherlands and holds a $\mathrm{PhD}$ from the same university. He has worked as an adviser on land reform and farmer resettlement in Luwu, South Sulawesi, and done extensive research in the same region on migration and transmigration, land reform, irrigation development, and local irrigation management. His most recent work on Indonesia focuses on decentralization and province politics in South Sulawesi. Dr Roth may be contacted at: <Dik.Roth@wur.nl $>$. 


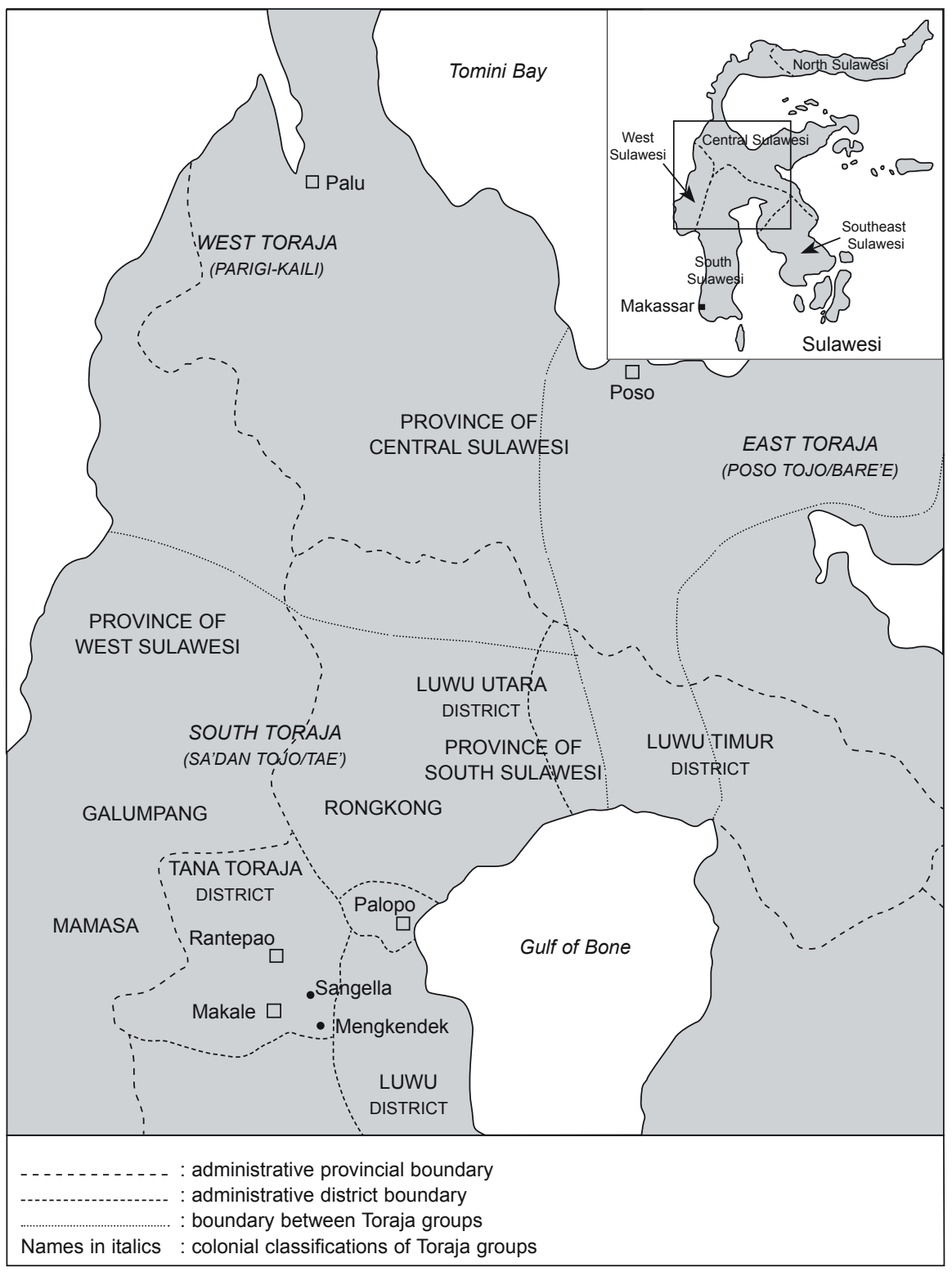

Map 1. Colonial classifications of Toraja groups and current administrative boundaries of districts and provinces 
Several regional autonomy movements have recently emerged in South Sulawesi. The strongest demands to create separate provinces came from northwestern and northeastern South Sulawesi (Morrell 2002, 2005). West Sulawesi Province, demanded from 1999, was established in $2004 .^{3}$ In the northeastern Luwu-Tana Toraja area, a movement emerged aimed at the creation of Luwu Province (or Luwu Raya Province). However, soon after its emergence a serious rift became visible. The main stumbling block was the shape of the intended province or, more specifically, whether or not to include Tana Toraja District in it.

This article about the Luwu-Tana Toraja region analyses some of the "changing continuities' behind this provincial autonomy conflict. Understanding these developments requires serious attention to the history of the relationship between Luwu and Tana Toraja, in particular discontinuities, tensions and conflicts pertaining to natural (as well as human) resources, changing identities, and definitions of territorial spaces and boundaries.

A major focus is the massive migration from Tana Toraja and highland Luwu to lowland Luwu with its abundant land resources. Because of its uncontrollable character and embeddedness in regional identity politics, migration became an extremely sensitive issue. Already during the New Order, lowland Luwu was regularly plagued by violent communal conflict along lines of ethno-religious identification corresponding to the divide between (mainly Christian) highland migrants and (mainly Muslim) lowland populations (Managing decentralisation 2003; Roth 2002). Such conflicts were often followed by waves of anti-Toraja sentiment and calls for closing Luwu to highland migrants.

This migration, therefore, needs to be analysed in the context of wider processes of change and of the emergence of 'Toraja' identity among the population groups currently inhabiting Tana Toraja and highland Luwu. The complex relationships between emergence of Toraja identity, expansion through migration and control of natural resources in lowland Luwu, and conflicts over political-administrative boundaries form the core focus of this article.

Recent studies show that growing attention is being paid to issues of migration, identity formation, control of natural resources, and resource conflicts. Peluso and Watts (2001), analysing violent resource conflicts, criticize simplistic models that assume direct causal links between 'scarcity' and conflict. The authors stress the need for analysis of specific local histories and social processes within larger transformations and arenas of power. Resource conflicts often intersect with tensions related to ethnic identity in periods of radical societal transformation. Constructions of ethnic differences and identities are often related to mechanisms for territorial control over natural resources. 
Aragon (2001) analyses communal violence in the Poso region, Central Sulawesi, from the late 1990s. Major features are the existence of a coastupland dichotomy defined in terms of differences between (coastal) Muslim and (upland) Christian groups, tensions related to migration and transmigration, and competition for land between locals and migrants in a context of economic problems, social tensions, and political power struggles. The disappearance of shared histories and cultural bonds and the redefinition of upland-lowland relationships along religious lines promote hatred and violence. Religion not only plays a legitimizing role, but also forms the basis for a process of territorialization. The tension between territory and ethnoreligious identity that has grown since colonial times is an important factor in the Poso conflict.

Li (1999) also discusses upland transformations and changing uplandlowland relationships. Constructions of upland 'marginality' and related dichotomies of 'tradition' and 'modernity', 'culture' and 'savagery', 'progress' and 'stagnation', are representations and identities constructed in the context of historical relations of power, accumulation and control. Upland 'traditions' should be regarded as the product of historical upland-lowland relationships rather than a symptom of upland stagnation and difference $(\mathrm{Li}$ 1999:5). Focusing on Central Sulawesi, Li $(2000,2001)$ argues that definitions of identity, difference and specificity, classifications of populations, and the drawing of boundaries are constructions with a long history in upland-lowland relationships. The existence of sharply drawn boundaries 'can be traced to specific histories of confrontation and engagement' (Li 2000:158).

My article contributes to these discussions by presenting material on the Luwu-Tana Toraja region. The second section introduces the regional context, briefly discusses the provincial autonomy movement, and explores regional history. In the third section I analyse the colonial construction of Toraja identity: the missionary roots of Greater Toraja, the changing meaning of Toraja, and its politicization in relation to emergent Toraja identity. The fourth section focuses on expansionist Lebensraum politics: migration to lowland Luwu. I discuss the changing character of highland-lowland migration, attempts to regulate migration to Luwu, and the issue of refugee settlement. Next, the focus shifts to changing boundaries: the Tana Toraja autonomy movement and regional suspicions of a Toraja Raya movement bent on incorporating Luwu. The next section focuses on continuing attempts to transcend new boundaries by restoring old bonds: the Makula agreement on migration and the 'LUTAT' movement. I conclude the article with a short reflection on changing continuities in Luwu-Tana Toraja relationships, relating my findings to recent debates about upland-lowland relationships. 


\section{Regional context and post-New Order developments}

\section{Tana Toraja and Luwu}

Tana Toraja District (Kabupaten Tana Toraja), covering some 3,000 square kilometres, has a population of about 400,000. Many people originating from Tana Toraja now live in neighbouring Luwu, other parts of Sulawesi, or elsewhere. ${ }^{4}$ Recently, even this relatively small district experienced a struggle for administrative change. ${ }^{5}$ Luwu District (Kabupaten Luwu), east of Tana Toraja and stretching around the Gulf of Bone, was, until 1999, the largest district in South Sulawesi, covering 17,791 square kilometres. In 1999, North Luwu District split off from Luwu. ${ }^{6}$ In 2003, East Luwu District (Kabupaten Luwu Timur) split off from North Luwu. ${ }^{7}$

\section{Luwu Province or Luwu Raya Province?}

In 1999, demonstrations in Luwu demanded creation of Luwu Raya (Greater Luwu) Province. According to a local newspaper, the province should encompass Luwu, North Luwu and Tana Toraja as '[...] these three districts still form a unity from a cultural-historical point of view. Geographically, the districts were once united in the Luwu kingdom.' The newspaper stressed that demography and the natural and human resources potential also support its formation. ${ }^{8}$ A declaration establishing the Badan Koordinasi Pembentukan Provinsi Luwu Raya (BKPPLR, Coordinating Body for the Formation of Luwu Raya Province), in which inclusion of Tana Toraja was specifically mentioned, followed in March 2001. ${ }^{9}$ In the same period, however, several declarations and documents appearing in Luwu and Makassar, capital of South Sulawesi, demanded a province covering pre-1999 Luwu, thus excluding Tana Toraja. ${ }^{10}$

The Komite Pusat Pembentukan Provinsi Luwu (KP3L, Central Committee for the Formation of Luwu Province) was formed in Makassar. One spokesman stressed the need to protect specifically Luwu ethnic and cultural values. Another spokesman also stressed the importance of Luwu identity, adding that '[...] from a socio-cultural point of view, the people of Luwu are indeed disappointed with South Sulawesi'.11 These people, and others who seek exclusion of Tana Toraja, tend to use the term Tanah Luwu (the land of Luwu)

\footnotetext{
4 The upper Sa' dan River forms the core of Tana Toraja. Following Bigalke 1981, for the period before Toraja identity became established, I use 'Sa'dan highlands' rather than 'Tana Toraja'.

5 Fajar, 25-1-2003.

Law $13 / 1999$.

Law $7 / 2003$.

Sawerigading Pos, 1-11-1999.

Media Indonesia, 1-4-2001; Suara Pembaruan, 1-4-2001.

Fajar, 4-11-1999, 7-2-2000; Palopo Pos, 1-5-2000.

Kompas, 26-2-2001, Tempo, 28-4-2001.
} 
or Wija to Luwu (the people of Luwu) rather than Luwu Raya. ${ }^{12}$ In reaction to the emergence of the Makassar-based group, in 2003 the Front for the Struggle for Formation of Luwu Province (FP3L) was established in Luwu to support a province that includes Tana Toraja.

Thus, the provincial autonomy movement is deeply divided as to the proposed provincial boundaries. ${ }^{13}$ Both parties legitimize their stance by using arguments based on the history of the relationship between the two areas. First, the Jakarta declaration on Luwu Raya Province:

We, the people of Indonesia originating from former Afdeling [colonial division] / Kingdom of Luwu, now known as the districts of Luwu, North Luwu, and Tana Toraja [...] hereby declare [...] that we struggle for the establishment of Luwu Raya Province, continuing the struggle of Andi Jemma, the King of Luwu, together with the people since 1953 [...]. Our determination to establish the province is based on the following considerations: first, the historical and cultural background and relations of kinship and origin between the people of Luwu and Toraja since hundreds of years that are still held in high esteem; second, the aspirations of the whole people of Luwu, North Luwu and Tana Toraja [...] for Luwu Raya Province to be immediately formed; third, the regional potential which fulfils the conditions for the establishment of an autonomous province, among others: the area, its population, its natural and human resources [...]. ${ }^{14}$

\section{Next, a Makassar-based spokesman of KP3L:}

Our point of view has to do with the past. In the 1950s, the Toraja separated themselves off from Luwu. Now the Luwu people do not want to join with them. Representing the aspirations of the people, we have to listen to their opinion [...]. We have already discussed the issue with the people of Luwu, and they simply do not want it. They say 'Luwu is Luwu only'. For the old generation Luwu and Tana Toraja are indeed one, but for younger generations things are quite different. It is a pity that there is this political background, of the Toraja stabbing their own brothers. Though we are regarded as ethnically the same, the people have another perception of that as well.

By 2004 provincial autonomy plans had completely stagnated. Though the recently adopted stricter law on administrative fragmentation ${ }^{15}$ and the established economic and other interests of South Sulawesi are important, the conflict over Tana Toraja is crucial in explaining this stagnation in the provincial autonomy movement. A further exploration of regional history is

12 Provinsi Luwu (Luwu Province) is used by both, though Luwu Raya usually refers to the inclusive option.

13 Information on conflicting views on Luwu (or Luwu Raya) Province is based on 2004 research through in-depth interviews in Jakarta, Makassar, Tana Toraja and Luwu. For more extensive discussion, see Roth forthcoming.

14 Deklarasi pembentukan Propinsi Luwu Raya, Jakarta, 31 Maret 2001.

15 Law 32/2004. 
indispensable for gaining a deeper understanding of the issues involved. From kingdom to districts

Until 1959 Luwu was a kingdom governed by a datu (king). Luwu is regarded as the cradle of Bugis culture (Errington 1989; Koolhof 1999). However, Luwu was (and is) not exclusively Bugis. The majority of the population speak Toraja (Tae') rather than Bugis. Luwu reached the apex of its power around the sixteenth century. Around 1605, the Luwu nobility converted to Islam. In the seventeenth century, the Bugis kingdom of Bone became the main power centre, while Luwu's power declined (Andaya 1981; Pelras 1996).

Control by the high nobility in the kingdom over local elites and their followers rather than direct, evenly spread territorial political control characterized Luwu's sphere of influence. Based on social and kinship ties, and shifting political alliances rather than fixed territoriality, political relations were dynamic and flexible. Luwu once included parts of current Central Sulawesi, Southeast Sulawesi, and South Sulawesi (Bigalke 1981; Pelras 1996; Volkman 1985).

Socio-cultural and political ties of Luwu with the Sa'dan highlands were important in regional politics, and remain so to this day. Kinship and other relations connected lowland Luwu with the highlands. However, the character and scope of these ties varied over regions and historical periods. Relations existed with the elites of the northern Sa'dan highlands and with Makale, Sangalla and Mengkendek, which represented the highest form of enduring political organization in the highlands. ${ }^{16}$

Such ties were expressed in myths of the divine and common origin of the early kingdoms of South Sulawesi: Luwu, Goa (Makassar), and Sangalla (Volkman 1985). Luwu's power was not recognized throughout the highlands. In the nineteenth century, Sangalla refused to accept Luwu's claim to superiority. ${ }^{17}$ Increasingly strong economic ties existed between the highlands and Luwu (and other kingdoms in South Sulawesi), mainly through elite networks engaged in the trade of slaves, coffee and weapons. Bugis cultural influence in the highlands grew rapidly (Bigalke 1981; Li 1999).

In the late nineteenth century the Dutch gave up their earlier policy of non-intervention in Sulawesi. In 1905, Luwu was incorporated into the colonial empire as a division of the Government of Celebes and Dependencies under a Dutch assistent-resident (Coté 1996). After taking over the lowland areas, Dutch troops went on to conquer the highlands of Luwu and the Sa'dan highlands.

In the process of subjugation, some of the existing ties of Luwu with

16 Small kingdoms in the southern Sa'dan valley, each ruled by a puang and called lembang. Hence Tallu' Lembangna (three lembang).

17 The puang of Sangalla played a key role in the accession ceremony of the Luwu datu (Van Lijf 1947; Volkman 1985). 
other regions were severed (with Wajo in South Sulawesi and Poso in Central Sulawesi) while others were artificially created or strengthened. ${ }^{18}$ Thus, the Sa'dan highlands were incorporated as the subdivisions of Makale and Rantepao of the Luwu Division. ${ }^{19}$ Though Luwu's political influence in the highlands had been decreasing, the Dutch assumed highland submission to Luwu. The decision to incorporate the highlands into Luwu led to fierce protests, especially from Sangalla. ${ }^{20}$ Thus, the Dutch had frozen dynamic and shifting political relations into fixed territorially based administrative units (Bigalke 1981; Errington 1989).

The Sa'dan highlands were of special concern to the colonial government in its struggle against Islam. Missionary activities had long been strictly regulated for fear of politically dangerous competition between Islamic and Christian missionary activity. As colonial policy changed to more active intervention, the government became bent on restricting the influence of Islam and preventing it from expanding into 'pagan' territories where colonial rule was still weak or absent. One important instrument was the Christian mission. As in the Poso area, where a Dutch missionary post had been established in 1892, the establishment of missionary activities in the Sa' dan highlands fitted in neatly with the main preoccupation of the colonial government: creating a buffer against 'incursion' of Islam from the Bugis lowlands. ${ }^{21}$

In 1914 the colonial government gave the Dutch Gereformeerde Zendingsbond (GZB, Reformed Mission) access to western Luwu (Makale and Rantepao in the highlands, and Palopo and Masamba in current Luwu). ${ }^{22}$ The coastal parts had long been under Islamic influence, while the highlanders had mainly animist beliefs (Van den End 1985; Pakan 1977).

\footnotetext{
18 The Dutch wanted to separate Poso from Luwu (Arts 1986:99-105).

19 Other subdivisions: Palopo, Masamba, Malili and Kolaka.

20 In 1935 the Dutch extended Luwu's power in the highlands. This was also fiercely protested in the southern highlands (Van den End 1991).

21 For Poso, see Arts 1986; Coté 1996; Schrauwers 1995, 2000. For a comparison of the 'ethical' Reformed Poso mission and the Reformed mission in the Sa'dan area, see Van den End 1991; Schrauwers 2000. Both were typical products of Dutch verzuiling ('pillarization'). The former worked towards establishment of a 'people's church' (volkskerk) based on Christianized local adat; the latter took a more distanced position. This also influenced debates about unification of the highlands. One impact of Dutch pillarization observed for Poso by Schrauwers (2000) - a Pamona ethnic identity largely defined in terms of religious affiliation (Christianity) - also applies to Tana Toraja; see below.

22 For buffer politics of the Indies Church (Indische Kerk), see Van den End 1985:106; Plaisier 1993.
} 


\section{Colonial construction of Toraja identity}

\section{Missionary roots of Greater Toraja}

For those associated with GZB, though they were sometimes critical of colonial policy, '[...] colonial rule was taken for granted. Mission and government were generally considered natural allies in the struggle against the common enemy, Islam. ${ }^{23}$ GZB directed much missionary effort at boundary areas between highland and lowland. Here a 'buffer' against Islam was to be established (Van den End 1985; Kobong 1989; Plaisier 1993). Thus, the linguistmissionary Van der Veen wrote in 1917 of the Rante Balla region in highland Luwu: 'as to missionary work, Rante Balla promises much for the future. [...] It is good that a firm stronghold be built there against Islam. ${ }^{24}$ Gradually these areas became the scene of fierce competition between Christian and Islamic missionary activity. ${ }^{25}$

Colonial and missionary ambitions did not stop at this pre-emptive strategy of Christianization. Mission and colonial government hoped that this policy would ultimately result in the creation of a Christian highland Sulawesi from which Islam would be completely banned. ${ }^{26}$ Thus, A.A. van de Loosdrecht, the first GZB missionary in the Sa'dan highlands, wrote to the Poso missionary-ethnologist A.C. Kruijt in 1916: 'you will have to admit that for the church of Poso it will also be very important if this [Sa'dan Toraja] region is Christianized. What a beautiful region it will be: all of Central Celebes for the mission.' (Van den End 1985:133.) Missionary Heusdens wrote in 1935: 'it has often been stated by government officials that it is the intention of the Netherlands Indies government to form one Christian block in Central Celebes, as happened in Sumatra by Christianization of the Toba Batak lands'.$^{27}$ In 1933, the issue of 'Greater Toraja' was voiced by the fiercely anti-Islamic missionary-teacher Saathof in the GZB monthly Alle den Volcke (Saathof 1933:55; Bigalke 1981:305). Though in missionary circles opinions were divided, ' $[. .$.$] the majority of missionary-teachers supported the action for$ autonomy of the Toraja lands. The ideal of one united and Christianized Toraja people, comprising all Toraja of the Sa'dan, Mamasa and Posso areas, was alive among them.' (Van den Endt 1991:247.)

Here we have come to the missionary and colonial roots of Greater Toraja. It was not just a vague ideal of cultural-religious unification, but an agenda for

23 Van den End 1985:45. The government saw the mission as a political ally, but also a possible source of political unrest (Plaisier 1993).

24 Van den End 1985:158. For the Protestant buffer in Central Sulawesi, see Aragon 2001.

25 L. Pronk, 'Memorie van bestuursovergave', 1935, pp. 472-81, in KIT Tropenmuseum, Amsterdam, microfiche archive 643. Bigalke 1981; Plaisier 1993; Sanusi Dg. Mattata 1967.

26 Interview with Th. Kobong, Jakarta, 1999.

27 Van den End 1985:347. On the policy of stimulating highland autonomy from Luwu from 1924, see Bigalke 1981:270. On (colonial) territorialization to control upland areas, see Li 1999. 
political and administrative change. ${ }^{28}$ What does 'Toraja' actually mean, and what is the history of Toraja identity?

The changing meaning of 'Toraja'

'Toraja' is associated linguistically with Bugis 'to ri-aja', 'highland people'. ${ }^{29}$ The term was used in the lowlands to refer to upland peoples of southern and central Sulawesi. Highlanders themselves probably never used the term 'Toraja' before the 1930s. ${ }^{30}$ A.C. Kruijt and N. Adriani, the first missionaries in Poso, known for their ethno-linguistic research, started using it after 1892. Using 'Toraja' as a basis for classifying the mountain peoples, they gave it a new meaning. It replaced the pejorative term 'Alfuru', then used by the Dutch for all non-Christianized or non-Islamized peoples of eastern Indonesia.

However, classifications like Kruijt's, based on a mixture of religious affiliation and cultural traits, were rather arbitrary and influenced by both a religious and a political agenda. ${ }^{31}$ Kruijt classified mountain groups into West Toraja (Sigi; Parigi-Kaili), East Toraja (Poso-Tojo), and South Toraja (Sa'dan). ${ }^{32}$ Linguistic classifications were used as well. Adriani (who did not use 'Toraja' but preferred 'Sa'dan' for the southern group) used 'Bare'e Toraja' for the East Toraja, according to the word used for 'no' or 'not' in the language of this group. Van der Veen, using the same criterion and following Kruijt's classification, called the South Toraja 'Tae Toraja'. ${ }^{33}$

\section{Politicization and ethnic identity: towards 'Toraja Raya'}

'Greater Toraja', incorporating all Christianized mountain peoples of the Sa'dan, Mamasa and Poso areas, originated from the Poso mission (Bigalke 1981; Van den End 1985, 1991; Saathof 1933:55). While in Poso the name 'Bare'e Toraja' was rejected and replaced by 'Pamona', in the Sa'dan area

\footnotetext{
28 Kobong (1989:158) uses 'regional nationalism'; see Van den End 1991; Henley 1993; Plaisier 1993.

29 As against 'to $l u u^{\prime}$ or 'lau' for the coastal population. Use of such dichotomies was common (Pakan 1977). See Nooy-Palm 1979:6-8; Bigalke 1981:13-6. On the derogatory meaning attached to upland (and upland people), see Li 1999.

30 On the amorphous character of population groups in Central Sulawesi, see Schrauwers 1994.

31 The basic distinction for mission and colonial administration was between lowland Islamized groups and (usually highland-based) non-Islamized groups, whatever other traits were shared by these groups (Schrauwers 1995, 1998; on Luwu and the Sa'dan highlands, see Bigalke 1981).

32 The latter included current Tana Toraja and Polmas Districts, the Galumpang and Makki' areas in Mamuju District, the Enrekang area south of current Tana Toraja, and the Pantilang, Rongkong and Seko areas in Luwu (Pakan 1977). Interview with J. Sarira, Rantepao, 1997; see Sarira 1975.

33 Pakan 1977. In colonial classification, the subdivisions of Toraja groups used by Kruijt were distinguished as Toraja 'law area', separate from the South Celebes law area which included the southern Makassarese and Bugis lowland, as well as Mandar, Luwu and Mori (Adamson Hoebel and Schiller 1948).
} 
'Toraja' caught on, as did 'Greater Toraja'. From the 1930s it came to be the expression of a supposedly common highland identity (Kobong 1989; Pakan 1977; Schrauwers 1995, 1998). From the 1920s, organizations emerged in the Sa'dan highlands to improve the socio-economic position of the Toraja and raise ethnic consciousness. As Indonesian nationalism was growing, emergence of a regional 'Toraja' identity suited the colonial administration (Bigalke 1981; Plaisier 1993). GZB missionaries were generally negative about nationalism, but far more positive about 'regional nationalism' (Van den Endt 1991). The GZB-controlled monthly Soelo (Torch), issued from 1932, banned nationalism but not the expression of Toraja identity (Bigalke 1981:293):

Aren't our Toraja lands the most extensive, if compared with the lands of the Bugis and Makassarese? [...] Therefore, all inhabitants of my Toraja people, especially the heads and those of noble origin, be unanimous and united, mutually supportive, helping one another, and living like brothers, so that in the end your name will be heard in Celebes as well. (Tandjong 1933.)

In the 1930s, Perhimpoenan Boenga' Lalan (PBL) was the first organization to openly state its objectives in terms of the advancement of a 'Toraja people' and 'Toraja land' (tanah Toraja) (Bigalke 1981). Even more important was Perserikatan Toraja Christen (PTC), established in 1936 by a group of young Toraja. ${ }^{34}$ Its objective was strengthening ethnic identity among Christian Toraja within and outside what was called tanah Toraja. PTC was one of the early sources of growth of ethnic identity among young Toraja. ${ }^{35}$

The Toraja demand for autonomy from Luwu was on PTC's political agenda. This demand had the covert and overt support of the mission, but was generally opposed by the colonial administration, who feared conflicts with the datu. Reinforced by highland anti-Bugis sentiment, the autonomy demand fitted in with political-administrative rearrangements envisaged by missionaries, parts of the colonial administration, and the new Dutch-educated Christian elite. In its extreme form, it involved incorporation of all highland groups into Greater Toraja (Bigalke 1981; Van den End 1985, 1991; Plaisier 1993). PTC was important not only in creating a basis for internal (Sa'dan) Toraja unity, but also in propagating the notion of Greater Toraja and passing

\footnotetext{
34 Members and leadership were mainly Dutch-educated. Leaders were teachers or members of the 'native' administrative corps (Bigalke 1981). Among them was Sampe Pongrante, also first PTC chairman. In 1937, Pemuda PTC was established in Luwu by Taula'bi. Both organizations played a key role in laying the foundations of Toraja emancipation in the lowlands (Interview with Th. Kobong, Jakarta 1999; see Kobong 1989).

35 Interview with Th. Kobong, Jakarta, 1999. A hidden PTC objective was establishing Greater Toraja (Plaisier 1993).
} 
it on to a new generation of politically active Toraja. ${ }^{36}$ Thus, in the 1930 s the emerging Toraja identity expressed itself in the Greater Toraja ideal. ${ }^{37}$

\section{Lebensraum politics: Toraja migration to lowland Luwu}

\section{From incidental labour migration to massive land settlement}

This section focuses on the postcolonial manifestation of Greater Toraja. In the 1950s the Greater Toraja ideal became a significant element in regional ethno-political ideology. In its new meaning, which reflected the growing strength of Toraja identity, it referred not only to the colonial project of consolidation and unification of Christian highland territories with 'Toraja' populations, but also to Toraja expansionist migratory and political ambitions towards lowland Luwu.

While Luwu was sparsely populated and covered with forests and marshes, the Sa'dan area was densely populated and characterized by conflicts between competing elites, high land prices, poverty, landlessness, and deteriorating tenure conditions. The people of lowland Luwu often traced their descent to the highlands and spoke the highland language. However, migration of highland-born people to lowland Luwu was rare. The highland population remained largely inward-oriented, tied to locality of origin by kinship, ritual ties, or bondage. Sometimes conflict, landlessness, or debts related to death rituals made people leave the highlands. Migrants tended to convert to Islam and completely assimilate into the lowland socio-cultural environment. ${ }^{38}$

In the 1930s, out-migration gradually increased under influence of the crisis and Dutch-imposed tax-payment obligations. Highland inhabitants in need of cash migrated in search of labour, or were employed in colonial construction works. This migration was often temporary; the destinations were sites of 'frontier' economic activity in Luwu (Van Lijf 1952; Volkman 1985). Some decades later, highland out-migration to and settlement in Luwu had become common. However, this migration became politically extremely sensitive. Early migration and more recent mass migration and settlement differ in more than quantity. The process of identity formation within a short period, making

36 Especially J. Linting, F.K. Sarungallo, and Sampe Pongrante, who belonged to the first generation but remained active in the period of emergence of a new generation of politically active Toraja like H.L. Lethe and W.L. Tambing (Interviews with Th. Kobong, Jakarta, 1999; L. Sombolinggi, Madandan, 1991, 1992, 1995, 1997; S.D. Tallulembang, Rantepao, 1997).

37 There was no general agreement among missionaries and administrators on unification of the Christian Toraja areas.

38 Bigalke 1981; Volkman 1985. Contrary to the Bugis, the Toraja are not mentioned as an outmigrating group in the 1930 census (Volkstelling 1931). On dense upland populations, see Reid 1997. 
religion the main boundary marker, has deeply influenced highland-lowland relations. A leading person of the Christian community in Luwu:

\begin{abstract}
There exists confusion in Luwu about which suku [ethnic group] lives here. I remember a discussion between politicians in Luwu in the early 1950s, in which a spokesman of the king of Luwu explained what the Luwu population was made up of. He said 'Toraja and Bugis'. Indeed, most people must have a Toraja background, you can see that from the language. Before the Dutch period, these people were largely animist and, once in the Islamic lowlands, adapted to local conditions including Islam. Having become Muslims they lost their Toraja identity. They would rarely call themselves Bugis, but neither would they use Toraja. For the generation of migrants that came to Luwu after 1950, things are different. Having become Christians before they left, they had already taken on a strong identity mainly determined by their Christian religion. Therefore, if you ask these people about their identity, they will answer proudly 'we are Christians, we are Toraja people'.
\end{abstract}

The above account points to a problematic side of Luwu identity as it developed in the twentieth century. Toraja identity was given the stamp of recognition, and Toraja culture became famous and attracted tourists from all over the world. Luwu had to make do with the glorious past of the kingdom but was primarily remembered as the regional basis of the Darul Islam rebellion (DI/TII, Darul Islam/Tentara Islam Indonesia, World of Islam/ Indonesian Islamic Army). Recent attempts to construct a specific Luwu identity can also be seen in the light of these developments. ${ }^{39}$

\title{
Towards a policy of regional migration
}

The 1940s was a period of rapid changes and social conflict in the Sa'dan highlands. The Dutch were aware of the threat of social conflict related to land, status, class and power (Van Lijf 1947, 1951, 1952; Bigalke 1981). To the east was Luwu, with its low population density, and land suitable for irrigated agriculture and settlement. In the late colonial period, plans for resettlement of highland inhabitants in lowland Luwu had been considered as a first measure to solve highland problems. Van Lijf (1952:274): 'the possibility was discussed of transmigration of some tens of thousands of Toraja'.

After 1950, when Indonesia had become a unitary republic, such plans for resettlement re-emerged (Bigalke 1981:393). Initially, post-colonial plans for mass migration resembled the Dutch plans in their analysis of socio-economic and demographic conditions and resource use in Luwu and Tana Toraja, and in their solutions. In 1951, a Panitia Locale Transmigratie (Committee for Local Transmigration) had been established, consisting of representatives of the Luwu administration and kingdom, including representatives both low- 
land and highland in origin. ${ }^{40}$ The report of a committee meeting mentions plans for migration of 20,000 families (50\% of the farmer families in 'Tanah Toraja') requiring 35,000 hectares of land on the North Luwu plain. The report stresses that 'this means that the Tanah Toraja transmigration can take place locally, and that the settlers will continue to live within the boundaries of Luwu'. ${ }^{41}$ Members of the highland and lowland elites, influenced by colonial conceptions of efficient resource use, started to see migration as the object of systematic planning and policy-making for regional development. The Committee was the first to attempt to organize such a migration.

\section{Politicization of migration: refugee settlement and Lebensraum}

Plans for local transmigration stopped upon the outbreak of the Darul Islam rebellion. ${ }^{42} \mathrm{DI} / \mathrm{TII}$ actions displaced many highland people, especially from those places in highland Luwu where Christian missionary activity had been highest. With DI/TII controlling the rural areas, refugees could not return safely to their areas of origin. Therefore, plans were worked out for resettlement in lowland Luwu. Negotiations between the Luwu nobility, administration (mainly Toraja officials), army, and affected highland populations resulted in the selection of locations in lowland Luwu where refugee groups could be resettled under army protection. Aside from the earlier colonial resettlement of Javanese, these settlements, established from 1952, were the first organized mass resettlements on the Luwu plain. They harboured hundreds of refugee households and, in the course of time, attracted many other migrant families.

The politicization of highland-lowland relationships under the influence of emerging Toraja identity and the rise of DI/TII was crucial here. ${ }^{43}$ In the 1940s the situation had grown increasingly tense. The position of the highlands and its population within the future administrative structure of Sulawesi had become a serious concern for Dutch-educated, mainly Christian, Toraja leaders. In Luwu, important changes were taking place as well. The demise of the kingdom as a 'self-governing territory' was now sim-

40 The committee had applied for government support but wanted to start migration irrespective of the availability of aid. The report shows it was influenced by the colonial discourse of efficient natural resource use: It stresses the agricultural potential of lowland Luwu and proposes catchment protection by resettlement of shifting cultivators in: Arsip Nasional Makassar (ANM), Tana Toraja (Tator) 1359.

41 ANM, Tator 1361.

42 In 1950 conflicts arose in South Sulawesi about the terms of incorporation of South Sulawesi guerrilla units into the regular Indonesian army and about centre-periphery relations more generally. Headed by Luwu-born Kahar Muzakkar, Darul Islam developed into a separatist revolt in South Sulawesi between 1950 and 1965. Kahar's death in 1965 marked the end of the movement (Van Dijk 1981; Harvey 1989).

43 Interviews in 1990, 1991, 1992, 1997 with L. Sombolinggi, Madandan; S.D. Tallulembang, Rantepao; P.S. Gasong, Seriti. 
ply a matter of time. The impact of the struggle for independence, nationalist ideology, and emergent party politics had made restoration of the status quo unlikely. ${ }^{44}$

In the early 1950s, as DI/TII expanded, the Luwu nobility was divided between supporters and opponents. ${ }^{45}$ Meanwhile, other actors appeared on the scene: first, the (Javanese) national army troops, present to establish and expand central control and protect the population against DI/TII. ${ }^{46}$ Second, there was the Dutch-educated administrative apparatus in Luwu, mainly Christians of Toraja origin. The short period of colonial and missionary presence in the highlands had given its inhabitants an educational advantage over their lowland Muslim neighbours. This was also reflected in the distribution of administrative functions. ${ }^{47}$ In the early 1950s the former Dutch subdivisions in Luwu were headed by three officials of Tana Toraja origin, all with a Dutch administrative educational background: W.L. Tambing in Palopo, H.L. Lethe in Masamba, and Sampe Pongrante in Malili. The first had also been initiator (and vice-chairman) of the Committee for Local Transmigration. With the others, he played an important role in negotiating the refugee settlements in 1952 (see above). He was involved in various other political activities and in the planning of military action. ${ }^{48}$ In 1955 he became a representative in the national council in Jakarta where, with J.K. Tumakaka from Central Sulawesi (see below), he represented the Greater Toraja ideal. ${ }^{49}$ Sampe Pongrante and Lethe had graduated from the Opleidingsschool voor Inlandsche Ambtenaren (OSVIA, Training College for Indigenous Officials). The former had been one of the foremen and first chairman of PTC in Tana Toraja (see above). Lethe had been head of the Tana Toraja regional administration (Tongkonan Ada'). All three were affiliated with Partai Kristen Indonesia (PARKINDO, Indonesian Christian Party; see below). ${ }^{50}$

\footnotetext{
44 In 1953, chairman of the Luwu regional parliament M. Guli wrote: 'I say that the whole population of Luwu [...] still love Andi Jemma but not the datu of Luwu', in: ANM, APS 208.

45 The political-administrative structure of the kingdom continued to exist (Andi Pangerang, Palopo).

46 The long-term Javanese interest was to establish a Javanese-dominated order through administration and transmigration.

47 On colonial education, see Harvey 1989. On the educational and more general privileging of Protestant groups compared to the Islamic coastal population and the resulting closer association between Protestant groups, mission and colonial power, see Aragon 2001.

48 The 1953 Toraja military action against Andi Sose; see below.

49 They are also associated with 'Toraja Raya' in a government publication. The option for administrative division of Sulawesi covering the Poso region and Tana Toraja is called 'konsepsi Tumakaka-Tambing' or 'konsepsi Propinsi Toraja Raya' (Sejarah daerah 1984:170).

50 Most Luwu government agencies were headed and staffed by Christian, Dutch-educated people of highland origin (interviews in 1990, 1991, 1992, 1997 with L. Sombolinggi, Madandan; S.D. Tallulembang, Rantepao).
} 
Third, party politics became increasingly important. In 1948, two PTC leaders had established the first South Sulawesi branch of the Indonesian Christian Party (PARKI), with support from the membership of social organizations like PTC. In 1950 this became PARKINDO, which grew rapidly under the influence of political events. There was a close association between political party and church, and a high degree of overlap between church membership and political preference. ${ }^{51}$ PARKINDO came to represent both Christianity and Toraja identity. The newly established Gereja Toraja (Toraja Church) and related organizations were closely interwoven with PARKINDO through leadership and members. ${ }^{52}$ In Luwu, PARKINDO support was also growing. ${ }^{53}$ Its growth was boosted by violence against Christian settlements and by successful Toraja military actions. ${ }^{54}$

The 1953 Andi Sose affair is a clear manifestation of Toraja assertiveness in lowland Luwu and the highlands. Andi Sose, a highland trader-warlord, had cooperated with DI/TII before defecting with his troops to the national army. They were stationed in Tana Toraja to combat DI/TII. ${ }^{55}$ Rumours of Sose's intentions led to his expulsion by Toraja defence units in 1953. Supported by the Toraja population, Tambing and Lethe had mobilized Toraja policemen and other officials stationed in Luwu. Planned and executed mainly from $\mathrm{Luwu}$, this action reflected the new highland-lowland relationship emerging under changing socio-political conditions. ${ }^{56}$

Massive migration and resettlement had their roots in changing views of Toraja identity, of relationships with the Bugis lowlands and Luwu, and of the future of 'the Toraja' in Sulawesi. Toraja political leaders tended to refer to these views and the accompanying political agenda as a search for 'Lebensraum'.${ }^{57}$ The core ideas were, first, that low population density and

\footnotetext{
51 Members of the Toraja church not affiliated to PARKINDO were sometimes regarded as 'not real Christians' (Interview with Th. Kobong, Jakarta).

52 Bigalke 1981. The Toraja Church emerged from GZB in 1947 (Van den End 1985:31).

53 This was reflected in the 1955 election results. See Harvey 1989; Bigalke 1981:432.

54 Conversions in the boundary areas showed a similar trend during DI/ TII (Van den End 1985; Plaisier 1993; Sarira 1975:44-8; Volkman 1985:42).

55 Sose's presence near the Javanese troops, associated with social upheaval and communism, was supported by the southern Sa'dan elites and Islamic community; these were united in antiJavanese, anti-communist, anti-colonial and anti-missionary sentiments, while for the elites the fear of revolution played an important role. The Javanese troops, in their turn, gave silent support to the 1953 Toraja action (Bigalke 1981:414-8).

56 In a letter to the governor dated 28-5-1953, Luwu district head Pattaropura advocated the transfer of Lethe and Tambing to positions where they could be controlled. The letter states that Toraja occupy leading administrative positions, 'yang masih merupakan "een doorn in het oog" dikalangan angkatan muda di Palopo' ('which is a thorn in the flesh of the young generation in Palopo', in: ANM, APS 285.

57 Associated with Friedrich Ratzel, Rudolf Kjellén, and Karl Haushofer, the term originates in nineteenth-century European geography and geopolitics, and became the legitimizing argument behind twentieth-century German expansion. Possibly Dutch-educated people like Tambing,
} 
underutilization of land in Luwu provided an opportunity for reducing highland social conflict and poverty. Therefore, access to those resources should be created for the Toraja population. These ideas were closely related to the emergence of Toraja identity. Toraja leaders felt that post-colonial highland-lowland relationships should be based on equality rather than on Toraja inferiority to the Bugis. Toraja expansion to Luwu through migration, supported by a growing sense of identity, was expected to increase Toraja social and political influence in the lowlands and redress old political imbalances. Third - and this was related to the Dutch blueprint for Greater Toraja - there was the wish to see this new identity reflected in the future administrative status of the highlands and Luwu in South and Central Sulawesi by separating these areas from Bugis-Makassarese influence. The outbreak of DI/TII gave such ideas an increasingly prominent place in Toraja politics, resulting in politicization, radicalization and ethnicization of highland-lowland relationships. ${ }^{58}$

\section{Politics of identity: struggling for new boundaries}

\section{Regional autonomy of Tana Toraja}

Radicalization of highland-lowland relationships boosted the Toraja struggle for autonomy. Earlier, the Sa'dan highlands had swung back and forth between incorporation into and autonomy from Luwu. ${ }^{59}$ In 1953 regional autonomy was highlighted by a resolution issued by PARKINDO in MakaleRantepao, followed by many statements supporting autonomy and formation of a Panitia Penuntut Otonomi Makale-Rantepao (Committee for the Demand

Lethe, and Sampe began using it. Interviews in 1990, 1991, 1992, 1997 with P.S. Gasong, Seriti; L. Sombolinggi, Madandan; S.D. Tallulembang, Rantepao; and interviews with F. Lande, Rantepao, 1996; F. Ratu, Palopo, 1991, 1992, 1997; J. Sarira, Rantepao.

58 Toraja leaders widely differed in their opinions. A major divide existed between those aspiring to Toraja 'Lebensraum' and the nationalists in favour of good relations between Tana Toraja and Luwu. For the latter, the ultimate criterion was the dividing line between the pejuang (revolutionaries) and those seen as cooperating with the Dutch. This distinction was also expressed in party affiliation, the former associating with PARKINDO, the latter with Partai Kedaulatan Rakyat (Interviews in 1990, 1991, 1992, 1997 with L. Sombolinggi, Madandan; and interview W. Sombolinggi, Sangalla, 1997).

59 Under Japanese occupation, Luwu had tried to tighten its grip on the highlands. In 1946, when the Dutch administration was re-established, the Dutch made Makale-Rantepao independent from Luwu. Called 'Tana Toraja', the former subdivisions of Luwu became a self-governing territory under the so-called Tongkonan Ada' government. In 1950, when Indonesia became a unitary republic, the pre-1946 situation was restored. Luwu, including Makale-Rantepao, was again recognized as a self-governing territory (swapraja). Separation of Makale-Rantepao from Luwu by the Dutch was a breach of the short declaration between the colonial government and Luwu (Van Lijf 1947; Schiller 1955). 
of Autonomy). ${ }^{60}$ Among its proponents was W.L. Tambing. ${ }^{61}$ PARKINDO in Luwu supported the autonomy demand. Political parties, social organizations, heads of agencies and administrations no longer recognized representation by the Luwu parliament. ${ }^{62}$ Autonomy was finally granted in 1957: Luwu was divided into Luwu and Tana Toraja. In 1959 both formally gained the status of district. ${ }^{63}$ The impact of this was enormous - for politics, the church, LuwuToraja relations, and the Toraja self-image.

Autonomy came like a shock to what remained of the Luwu kingdom. However, leading Toraja politicians felt that, in the struggle for new administrative units, they should not let this opportunity pass. They did not doubt that an autonomous Tana Toraja would be better off. ${ }^{64}$ One former politician:

I remember a meeting in Rantepao, chaired by Tambing and Sarungallo. All people present but one agreed with the demand for autonomy. This one man said: 'If we separate ourselves from Luwu, you will repent it. First, our road down to Luwu will be closed, so we will lose our opportunity for filling up Luwu with local transmigrants. Second, we will lose our position in Luwu in other respects as well.' All the others laughed at the man. They said 'we must separate, we need a strong basis: Tana Toraja. For that reason we are pro.' But, in a way, this man was proved right by later developments. ${ }^{65}$

Struggling for autonomy, Toraja leaders had not considered its consequences. They aimed at a district representing Toraja identity. Later, many politicians realized that something had been lost. Autonomy was regressive in moving away from the broad definition of 'Toraja' as basic to the Toraja Raya ideal. Here follows the analysis of one former politician of highland Luwu origin, who supported Toraja political emancipation, but was aware of the arbitrariness of the new administrative boundaries they were striving for: ${ }^{66}$

The autonomy ideal stemmed from the feeling that Makale-Rantepao should be able to manage its own affairs. As section head of a government agency I joined the provincial delegation that attended the ceremony in Tana Toraja to celebrate its autonomy. I remember that there were Javanese and people from other areas saying, 'This is stupid. Why should the Toraja separate from Luwu? If they con-

\footnotetext{
60 ANM, Tator 587.

61 Another was Sarungallo. See ANM, APS 244.

62 ANM, Tator 587.

63 Emergency Act No. 3, 1957 (16-1-1957). Tana Toraja was established on 31-8-1957. See ANM, Tator 590. Luwu was established by Law No. 29, 1959 (4-7-1959), which replaced Emergency Law No. 3. See ANM, Tator 587, 590; ANM, APS 244.

64 Interviews in 1990, 1991, 1992, 1997 with L. Sombolinggi, Madandan; S.D. Tallulembang, Rantepao.

65 Interviews in 1990, 1991, 1992, 1997 with S.D. Tallulembang, Rantepao.

66 Especially the population of highland Luwu was in a difficult position. Socio-culturally they identified with Tana Toraja, historically they belonged to Luwu. Competition between the Christian mission and Islam added to this complexity.
} 
tinue to be part of Luwu, they will occupy the area within twenty-five years.' The Toraja were so preoccupied with the wish to split off that they did not consider the potential of lowland Luwu and see future Luwu-Toraja relationships in the light of such potential. There was little consistency in this policy, which was most fanatically propagated by the same people who had in mind the administrative unification of an area much larger than Makale-Rantepao. In discussions I used to say: "There is a Toraja word diserekki, "exclusion from a common bond". Seized by emotion, proponents of autonomy put their bets on Makale-Rantepao, which they called Tana Toraja. But the area thrown out of the common bond is much larger than Tana Toraja itself.' I said: 'I would have fully agreed if we had used "Tana Toraja Tengah" (Middle Tana Toraja), meaning that the areas to the south, the north, the east and the west still belong to Tana Toraja.' But Tana Toraja District, as it is called now, means that only this is their place, and the rest is migration. Used in this manner, 'Toraja' is a restrictive concept. Let me ask you: is there a Tana Bugis District, is there a Tana Jawa District? No! There are still people who take pride in the existence of Tana Toraja. They regard it as a victory, something worth defending. ${ }^{67}$

This interpretation of 'Tana Toraja' as a restrictive concept is widespread. It contradicted the Toraja Raya concept as an expression of socio-cultural bonds connecting highland population groups. Hence, it excluded population groups that identified with Tana Toraja, like the population of highland Luwu, from being 'Toraja'.

J.K. Tumakaka, a republican of Central Sulawesi origin stationed at the Luwu court of justice in the early 1950s, did not support Tana Toraja autonomy. He favoured creation of a larger administrative unit comprising all 'Toraja' groups of colonial classifications (one of the few Sulawesi politicians in national politics, he represented the Toraja Raya ideal there in the 1950s). ${ }^{68}$ His negative opinion of Toraja autonomy was based on an analysis of ongoing social struggle in Tana Toraja, the demography of Tana Toraja and lowland Luwu, and the resource potential of the latter:

Working in Luwu I saw that a solution should be found to the problems of Tana Toraja. I rejected a violent social revolutionary course. The problems should be solved through local transmigration rather than land seizures and other violent actions: migration to Luwu with its underutilized land, but also to Poso and Mori. My support for Toraja Raya was based on the following considerations: first, economically, the need for human labour power in Luwu and other areas, and for land, for Lebensraum, in Tana Toraja, were complementary. Second, the Toraja region should become an important and stabilizing political factor. National

67 A distinction is sometimes made between Tana Toraja (the current district) and Tanah Toraja ('the areas inhabited by the Toraja people, in particular the Districts of Tana Toraja and Luwu'; Sarira 1975; Kobong 1989).

68 With W.L. Tambing (see above; Sejarah daerah 1984). Interviews in 1990, 1991, 1992, 1997 with L. Sombolinggi, Madandan; and interview with J.K. Tumakaka, Jakarta, 1999. 
interests coincided here with regional interests. In 1957, when PERMESTA ${ }^{69}$ broke out, I was convinced that the Toraja people could play an important role in fighting DI/TII and PERMESTA. Third, the Toraja people had been ethnically, linguistically and culturally classified as one. I agreed with Toraja Raya if it would remain loyal to the republic. However, Toraja Raya sounded like a threat to other regions, so I used it with great care. According to specialists in adat and linguistics, the whole area had been classified as one rechtskring (law circle). There was broad agreement that Sulawesi should be subdivided into provinces. One option was to join Central Sulawesi with Tana Toraja and Luwu into what would become known as Toraja Raya. Bugis politicians from South Sulawesi, who regarded loss of Tana Toraja and Luwu as a major threat to their interests, fiercely rejected this idea. Returning to the issue of autonomy: in view of these considerations, what was the use of it? I could not see the point of the Toraja locking themselves up within the confines of Tana Toraja, while in Luwu important administrative positions were in their hands and land was still largely unused. This also explains why Luwu did not resist the Toraja autonomy movement. With the presence of so many Toraja officials, people in Luwu felt themselves overruled by Toraja. All government institutions in Palopo were filled with educated Toraja. So when the Toraja demanded autonomy, it was seen as a good opportunity to get rid of them. The outcome proved that the decision to separate from Luwu was wrong. Though fiercely in search of Lebensraum, they ended up isolating themselves within their district. Opportunities for the educated in search of administrative functions and for the poor in search of land were reduced. ${ }^{70}$

Along with autonomy, migration too became a political issue. Toraja migrants in Luwu were increasingly regarded as strangers encroaching upon Luwu. Autonomy also marked the beginning of the disappearance of (Christian) Toraja government personnel from Luwu and their replacement with lowland people. After that time, there were hardly any Toraja officials in leading positions in Luwu government agencies.

\section{Politicization of highland-lowland relationships: the spectre of Toraja Raya PERMESTA complicated the political situation when it spread to Central Sulawesi. If, as was feared, PERMESTA were to join up with DI/TII, regional- ism would tear Sulawesi apart. ${ }^{71}$ In 1957, PERMESTA leaders had proclaimed North Sulawesi Province, independent from Makassar and including Central}

69 PERMESTA (Perjuangan Semesta Alam, Inclusive Struggle): another regionalist movement in Sulawesi. Started in 1957 in Makassar, its main demands were provincial autonomy for Sulawesi, greater say in military and political-administrative affairs, development of Sulawesi, and a more equitable distribution of economic benefits. From 1958, in northern Sulawesi the movement developed into a full-fledged armed rebellion, affiliated with the PRRI (Pemerintah Revolusioner Republik Indonesia) rebellion proclaimed in West Sumatra in 1958; hence it is often referred to as PRRI/ PERMESTA (Harvey 1977).

70 Interview with J.K. Tumakaka, Jakarta, 1999.

71 According to Bigalke (1981:436), Toraja PARKINDO leaders explored the possibility of cooperating with (Christian) PERMESTA leaders in North Sulawesi. 
Sulawesi. In reaction, local resistance movements emerged, ready to fight PERMESTA (and DI/TII) but posing their own autonomy demands. One such movement in Central Sulawesi was Gerakan Pemuda Sulawesi Tengah (GPST, Central Sulawesi Youth Movement), established in Poso in $1957 .{ }^{72}$ GPST received material support for its struggle from Jakarta. The military command in Sulawesi had allowed it to work toward formation of Central Sulawesi Province in Jakarta, as long as this did not include Tana Toraja and Luwu. ${ }^{73}$ Similarly, various Tana Toraja defence groups were supported by the government and the national army in their struggle against DI/TII. Hence, the situation in Luwu was very unstable. ${ }^{74}$ In this period Toraja Raya became an issue again. J.K. Tumakaka:

The press often gave the impression that Sulawesi was in the hands of PERMESTA. I always denied this, stating that the Toraja people in Central Sulawesi - Makale, Rantepao, Poso, and Mori - formed the largest ethnic group in Sulawesi and were still loyal to the republic [...]. If Toraja forces could be united against PERMESTA and DI/TII, that would be a major support to the central government. This was fiercely resisted by the Bugis adversaries of such plans, who spread the rumour that it was a separatist movement. In this period, the political strategies and objectives of the national government coincided with regional interests like formation of Toraja Raya [...]. I approached these issues from a different perspective than Tambing, the Southern Toraja representative in national politics, and local Toraja politicians. While he still attempted to solve regional problems regionally, I preferred to solve them nationally. I did not consider the local situation from a local perspective only. I saw more than Lebensraum and Toraja autonomy. I saw the Toraja people as having enormous human potential. In the national interest I decided to support GPST. It could contribute to the defeat of regionalist movements, and was a way of channelling military aspirations and heroism of local military groups. In those days, the army was still idealized and thought of as something terrific. I introduced the GPST leaders and intellectuals from Poso to the president and made sure they would receive military training and support in the national interest, to prevent Sulawesi from falling into the hands of DI/TII in the south and PERMESTA in the north. The Toraja were in between, and I happened to be here as their representative.

Much had depended on the (Toraja) troops under another Toraja leader associated with 'Toraja Raya', Frans Karangan, based in Central Sulawesi. In

\footnotetext{
72 GPST formally affirmed support to the central government, stated its goal of freeing Central Sulawesi from PERMESTA, and lobbied for Central Sulawesi Province. Early in 1958 GPST leaders went to Java for formal recognition and material support, and to lobby for Central Sulawesi Province (established early 1960s) (interview with Herman Parimo, Kasintuwu, 1997; see also Sejarah daerah 1984; Schrauwers 1995).

73 Interview with Herman Parimo, Kasintuwu.

74 Especially in 1958 when PERMESTA troops had entered North Luwu and joined DI/TII forces (see Aragon 2001), resulting in new attacks on towns in North Luwu (Interview with Herman Parimo, Kasintuwu).
} 
1957 he decided to remain loyal to the central government rather than joining PERMESTA. Thus, the direct danger of the forces uniting into a military movement for Toraja Raya had receded..$^{75}$ The few available sources on Luwu indicate that the issue still played a role there in 1958. Rumours were circulating in Luwu and Tana Toraja that Javanese troops would be replaced with units commanded by Andi Sose. After Toraja protests had proved in vain, Toraja defence forces - possibly with Javanese army support - expelled Sose's troops from Tana Toraja again. ${ }^{76}$ Thus, the relationship between Tana Toraja and Luwu was again put to the test. The Javanese troops were accused of supporting Toraja units against Sose and, hence, supporting Toraja Raya. A letter from Andi Jemma, last datu, to the Governor of Sulawesi in October 1958, shows this fear of Toraja Raya:

Luwu has become a base of retreat for the Toraja Raya movement, and actually the leadership of the regional military command [...] gives moral and material support to the movement, as evidenced by the fact that Luwu society has witnessed members of the Toraja Raya movement running around with firearms, brutally intimidating the people of Luwu. However, we were able to convince the people not to undertake anything that could worsen the situation. [...] Then, in early 1958, in view of the fact that this situation [...] was dangerous for Luwu and its people, a secret meeting was held at the initiative of the chairman of the Luwu district parliament in which it was decided to immediately send Andi Achmad to Makassar as representative of the district head to report this affair to the government. It was also decided that he should continue to Jakarta to request full government attention, as Luwu had become the object of the Toraja Raya movement, even though the people of Luwu rejected the Toraja Raya ideal.

According to the letter, the Luwu administration reported these incidents to the military command in Makassar through two of its members, one of whom is mentioned above. After they were threatened by the military, the letter continues, the District Representative Council finally decided to discharge them from their function. This last decision is fiercely protested in the letter:

It is clear [...] that this decision was taken only to realize the plans of the Toraja Raya movement through the PARKINDO representatives in the district parliament of Luwu; for this, W.L. Tambing came to Palopo under the protection of Brawijaya

\footnotetext{
75 Bigalke (1981:437) writes that Karangan and another military leader, Gerungan, 'began to collaborate on organizing a Greater Toraja movement in Central Sulawesi that would associate with PERMESTA'. However, after a short period of cooperation they went their separate ways again, the former joining TNI and the latter PERMESTA and later DI/TII. With reference to Toraja Raya, Bigalke (1981:437) concludes: 'Frans Karangan's decision to remain loyal to the TNI meant the end of Greater Toraja as anything more than a dream [...]. To challenge Jakarta was to jeopardize their only reliable outside support against these guerrillas in exchange for an uncertain alliance of Christian highland peoples.'

76 See Harvey 1989:291. For PARKINDO as 'guardian of Torajan ethnicity', see Bigalke 1981:441.
} 
[Javanese] troops to arrange it all, dividing the Luwu leadership by using violence. This time Tambing, who holds the presidium of the movement for Toraja Raya Province, will not succeed in reaching his objectives through violence and dividing our leadership, as long as the Luwu leadership remains firmly in place. [...] Recently the Luwu representative council has clearly become the channel for reaching the objective of Toraja Raya, to which the majority of the people of Luwu are opposed because they do not want to break away from the union of South Sulawesi [...]. ${ }^{77}$

Thus, Toraja Raya still played a role in regional politics, both as a political ideal and as part of the image of Toraja in the eyes of lowland politicians who were bent on separating from Makassar, expanding into Luwu, and establishing Toraja Raya. ${ }^{78}$ Gradually the Toraja Raya ideal died away. However, the complex issues of identity, tensions related to changing boundaries, and large-scale migration and land settlement continued to play a role.

\section{Transcending boundaries: Makula agreement and LUTAT}

\section{Makula agreement}

Early in the 1960s, an agreement was concluded about controlled migration between Luwu and Tana Toraja, locally known as the Makula agreement. ${ }^{79}$ Those involved at the time in politics or administration still remember 'Makula', but it is not documented in the Luwu or Tana Toraja archives. ${ }^{80}$ The agreement is remarkable for its focus on large-scale local migration, seen as beneficial for both areas, and for its unifying message of basic socio-cultural unity of the districts, notwithstanding administrative separation. One person from Luwu involved in Makula:

The point of departure of the conference was that the two areas are like brothers. In the official statement accompanying the agreement it was stressed that Luwu and Tana Toraja [...] cannot be separated in a geographical, socio-economic or political sense. So in developing these regions, local transmigration on the basis of this special relationship was needed [...]. It was even stressed that, though formally separated administratively, the areas are still one in a socio-economic, geographical and cultural sense. I agreed with the message of Luwu and Tana Toraja being one. This conceptualization of relations between the areas moved one step away from the earlier restrictive concept of Tana Toraja.

77 Datu Andi Jemma to Governor of Sulawesi, 28-10-1958, in: ANM, APS 198.

78 In Luwu, Toraja Raya was sometimes called Menunggu Belanda Datang (waiting for the Dutch to come; rumours circulated that one day the Dutch, still in New Guinea, would come to the aid of Christians in Sulawesi) (Interviews in 1990, 1991, 1992, 1997 with L. Sombolinggi, Madandan).

79 Named after the place in Tana Toraja where a conference on migration was held.

80 Based on interviews in 1996 with, among others, Y. Duma, Makale; D. Palamba, Makale; J. Salubongga, Rantepao; U. Salurapa, Rantepao; S. Sampe, Rantepao. 
In those days, Toraja officials still held key administrative positions in Luwu and thus formed a strong power bloc in favour of local transmigration. Further, migration from Tana Toraja to Luwu had the support of leading members of the Luwu nobility, whenever migrant agricultural activities could set a good example for the local population. Like the Tana Toraja elites, members of the Luwu nobility regarded sago production, a major source of lowland livelihood, as an obstacle to progress and development, associating it with laziness, backwardness and stagnation. They felt that development required a higher population density, preferably provided by Toraja farmers. Settlement in Luwu, then, was seen as a stimulus for development. It was primarily the uncontrollable character of in-migration that was seen as problematic. ${ }^{81}$

Makula was intended not only to initiate and encourage migration under responsibility of the district administrations, but also to restrict uncontrolled migration. Migration and settlement took place in an increasingly unregulated and uncontrolled way. Migrants in search of land entered Luwu outside of official procedures. After selling land, a buffalo or other highland possessions, they invested the proceeds in cheap and widely available land in lowland Luwu. Once settled, they sometimes registered to formalize their presence and land claims. In the final years of DI/TII, with peace and order returning, uncontrolled migration and settlement rapidly increased. ${ }^{82}$

The agreement actually set the agenda for new local transmigration. Several settlements in lowland Luwu are associated with the Makula agreement. Some of them were a direct outcome of the agreement. From 1964, some of these settlements were threatened by operations of DI/TII units in North Luwu. Local leaders affiliated with DI/TII did not accept the presence of these settlements. After 1965, when DI/TII had been beaten, these tensions remained. The changing attitude of the district administration is said to have caused these tensions. The administration had come under increasingly strong political pressure to withdraw support from local transmigration. This enraged PARKINDO leaders in Luwu and led to further politicization of the migration issue. The Makula agreement, though never formally terminated, lost its relevance in an atmosphere of political opposition against migration. Hence, while organized migration stopped, unregistered and uncontrolled migration increased. A former politician:

\footnotetext{
81 Fear among Luwu elites that national transmigration would probably select Luwu as a target area also played a role here. Against the background of these fears, the Makula plans reflected a general preference for land allocation to highland anak daerah (people from the region) rather than Javanese orang lain (strangers). For reasons of space I cannot go into these issues here.

82 The refugee settlements, for instance, attracted many migrants from highland Luwu and Tana Toraja.
} 
PARKINDO politicians in Luwu had agreed to formal regulation of local transmigration through the Makula agreement. Many people in Luwu wanted such settlement, but political parties were divided. Islamic parties tended to be against, and sometimes actively blocked it. See what happened to the formally approved settlements: these were still complained of and even threatened by violence. The open and official character of agreements about local transmigration did not work, and caused their failure. Establishing committees or creating regulations for local transmigration were like awakening a sleeping tiger.

PARKINDO politicians embarked on a new strategy, no longer based on official regulation but on existing socio-political (church, political parties) and kinship networks in Luwu and Tana Toraja. This 'silent strategy', as one politician called it, proved successful. After the Makula agreement had been mothballed, this kind of migration and settlement increased. Luwu was flooded with transmigrasi gelap (illegal transmigration). Increasingly, people from Tana Toraja came on their own initiative. This migration reached its peak in the 1970s and 1980s. Later, destinations like Southeast and Central Sulawesi became increasingly important. Influenced by the Sulawesi cocoa boom, recent destinations of Toraja migration are agro-ecological zones suitable for cocoa cultivation rather than irrigated agriculture. ${ }^{83}$

\section{'LUTAT affair'}

Before Soeharto's New Order, Luwu-Tana Toraja relations surfaced once more in regional politics. LUTAT (Luwu-Tana Toraja) refers to attempts in the early 1960s to establish a province combining Luwu and Tana Toraja. ${ }^{84}$ LUTAT arose in the early 1960s among Java-based Luwu and Toraja intellectuals. The main political objective of this movement, as had been the case with Toraja Raya, was autonomy from South Sulawesi. There was a similar awareness of the complementary resources of Luwu (land) and Tana Toraja (labour; educated people), and the artificiality of existing boundaries. However, a younger generation was involved than in Toraja Raya, free from colonial missionary influence and Toraja Lebensraum ideas. While Toraja Raya was the product of Toraja identity formation along religious lines, LUTAT stressed common historical ties between highland and lowland populations across existing administrative boundaries.

With government control in South Sulawesi almost restored, it was more difficult than before for regional leaders to negotiate demands for administrative rearrangements with Jakarta. Central Sulawesi was well on its way to recognition as a province. This made Toraja Raya difficult to accomplish. 
Gradually, fusion of Luwu and Tana Toraja into one province emerged as another option to gain autonomy from Makassar.

LUTAT enjoyed broad support among the Luwu and Toraja elites. Resolutions supporting LUTAT were prepared in both districts, and presented to the Ministry of the Interior. The movement stressed the non-separatist character of LUTAT, and made Andi Jemma, last datu of Luwu and pejuang (hero) of the revolution, its figurehead. ${ }^{85}$ The group assumed that his merits would guarantee success, and also planned a visit by Andi Jemma to the president to lobby for LUTAT. Andi Jemma had been informed about the plans and discussed them with the Java-based group. He supported the idea, regarding it as his final contribution to the development of Luwu. President Soekarno had no objection, and expressed his support on 23 February 1963. ${ }^{86}$ In the end, LUTAT did not materialize. Obstruction by South Sulawesi elites and growing national political turbulence seem to have caused its failure. A person formerly involved in the movement:

Our main objective was to rule ourselves, independent from Makassar. That was a very sensitive issue, especially in our relationship with South Sulawesi. Andi Jemma had discussed these matters with our group and the idea, including separation from South Sulawesi, was acceptable to him. In fact, our action came too late. When we started lobbying for a province, Andi Jemma was already ill. Had he demanded a province just after independence, he would certainly have been given it. But after the regional troubles in the 1950s and all the changes in the kingdom, other options were favoured. Andi Jemma was no longer the influential national revolutionary hero. His influence had declined, and he had become increasingly dependent on higher-level politics in Makassar. Moreover, the Bugis rejected a future South Sulawesi without Luwu and Tana Toraja.

However, for Luwu that was not the end of the story. LUTAT continued to buzz around after 1965. In 1966, for instance, the Luwu district head was fired after signing a petition demanding LUTAT and presenting it to the Minister of the Interior. Just after DI/TII and the 1965 coup, any promotion of administrative changes by a district head was anathema to Indonesian politics. That marked the end of LUTAT, until the late 1990s.

\section{Changing continuities in Luwu-Tana Toraja relations}

I started this article with a short account of the Luwu Province autonomy movement that re-emerged in the late 1990s. While those supporting a province including Tana Toraja cite common histories, resources, identities and boundaries, those against inclusion stress potential conflicts, differences, and

85 There were plans to make Andi Jemma governor (interviews in 1990, 1991, 1992, 1997 with L. Sombolinggi, Madandan).

86 Andi Jemma died two years later, in 1965. 
the need for administrative separation. Accounts by people involved in the latter group emphasize the tensions: the recent history of conflict related to Toraja migration and competition for land in Luwu, expected competition for power in a new province, differences along religious lines, and Luwu's probable inability, in the face of Toraja influence, to put itself on the map by giving the province a specifically (Islamic) Luwu identity rather than a mixed Luwu-Toraja identity. ${ }^{87}$

This conflict has seriously delayed the process, giving the current province (South Sulawesi) strong arguments for refusing the demand for a new province because it is not clear which version deserves recognition. In the meantime, a stricter law on administrative change has made its formation very unlikely without cooperation between Luwu and Tana Toraja. By late 2004, many people in Luwu and Tana Toraja were becoming disillusioned with the movement.

My account shows that there is much continuity between developments in the 1950s and 1960s (Greater Toraja/LUTAT) and the recent provincial autonomy movement. Rather than merely being the product of post-Soeharto decentralization policies, these recent developments illustrate the importance of understanding historically complex Luwu-Tana Toraja relationships in which conflicts about resources, identities and boundaries have a prominent place. I have traced here the interrelationships between emergent Toraja identity in the Sa'dan highlands, a search for 'Lebensraum' through migration to lowland Luwu, and struggles over political-administrative boundaries.

Based on the fiction of ethnic unity of highland populations that had guided the colonial-missionary Greater Toraja ideal, its post-colonial successor Toraja Raya continued to be meaningful in the 1950s. Toraja identity was also related to the emergence of migration strategies oriented to lowland Luwu. 'Lebensraum' and 'Toraja Raya' were guiding concepts of a generation of Toraja politicians concerned with the future of 'the Toraja people' in South Sulawesi.

Though a new province did not materialize, issues of identity, migration in search of land, and the struggle for new boundaries continued to play a role in the 1960s. The Makula agreement was an attempt to regulate migration from the highlands to lowland Luwu. On the political-administrative front, LUTAT attempted to sever Luwu and Tana Toraja from South Sulawesi. It clashed with the same South Sulawesi interests against provincial autonomy for Luwu and Tana Toraja that had played a role earlier, and continues in the current struggle about Luwu (or Luwu Raya) Province.

Relations between identities, territorial spaces and boundaries, and resources are complex. Recent work on identity has shifted from essentialist approaches to a focus on conceptions of identity as socially constructed

87 Based on interviews held in Jakarta, Makassar, Tana Toraja and Luwu in September, October and December 2004 with political actors and observers of the Luwu Province autonomy movement. 
(Smith Kipp 1993; Smith Kipp and Rogers 1987). Essentialist images of 'the Toraja' as a 'tribal minority' in a distinct geographical space with clearly demarcated boundaries (Tana Toraja) are not appropriate. Toraja political leaders were torn between two images of Toraja identity and related political-administrative options. 'Greater Toraja' did not fit the political realities of the 1950s. Identification with Tana Toraja District was increasingly seen as a straitjacket that confined 'real' Toraja identity, as it excluded highland groups that identify socio-culturally with the Tana Toraja population. Both were ideological constructions of relationships between people, collective identities, and territories (like LUTAT and the current competing orientations in the provincial autonomy movement).

Returning to debates about resource conflicts, highland-lowland relationships and identities, I have shown here that, as in the Poso area (Aragon 2001), highland and lowland identities developed historically along the dividing lines of religious affiliation. This shift of identities resulted from a relatively short period of rapid social and political transformation. Toraja identity also stimulated an expansionist territorial definition of that identity: Greater Toraja and Lebensraum thinking. Starting as a colonial construction, Toraja identity had become a political ideology of 'regional nationalism' (Kobong 1989; Henley 1993). Its ambition was to turn historically grown upland-lowland relationships upside down by using the upland educational advantage and access to key administrative functions inherited from the colonial period. Upland difference, defined in terms of Toraja identity, was a source of political agency, putting into perspective widespread images of upland inferiority, marginality and backwardness (Li 1999, 2000).

Expansionist thinking was primarily oriented to the land resources of lowland Luwu. Upland-lowland migration had occurred in earlier times, but it became politically sensitive under the influence of an ongoing process of territorialization based on a newly formed, mainly religious, identity. Toraja migration and settlement to lowland Luwu came to be associated with expansionist identity politics. This specific history of upland-lowland relationships explains why land-related conflicts in lowland Luwu have often developed into communal conflicts along religious lines: resource control cannot be isolated from the processes of identification that have helped shaped these patterns of control (Peluso and Watts 2001).

The recent conflict about the territorial definition of a new province (like earlier LUTAT) is indicative of a struggle between, on the one hand, views about territoriality, boundaries and identities that transcend the divisive trends of the recent past and stress a common upland-lowland history, and, on the other hand, views that build on divisive elements (Aragon 2001). Both views are idealized constructions. The former bases the province upon an idealized image of upland-lowland relationships in the Luwu Kingdom during the colo- 
nial period. The latter seems to be guided by the wish to establish a province with a specifically Luwu and Islamic identity, administratively autonomous but closely related through religion to the Bugis-Makassarese world.

\section{References}

\section{Unpublished sources}

Arsip Nasional Makassar

APS

Luwu

Tana Toraja

KIT Tropenmuseum, Amsterdam

L. Pronk, 'Memorie van bestuursovergave betreffende de Onderafdeeling Palopo van den aftredenden controleur: dr. L. Pronk', 1935, microfiche archive 643.

\section{Published sources}

Adamson Hoebel, E. and A.A. Schiller

1948 'Introduction', in: B. ter Haar, Adat law in Indonesia. Translated from the Dutch by George C.O. Haas and Margaret Hordyk, pp. 1-43. New York: International Secretariat Institute of Pacific Relations. [Originally published as Beginselen en stelsel van het adatrecht, Groningen: Wolters, 1939.]

Andaya, Leonard Y.

1981 The heritage of Arung Palakka; A history of South Sulawesi (Celebes) in the seventeenth century. The Hague: Nijhoff. [KITLV, Verhandelingen 91.]

Aragon, Lorraine V.

2001

'Communal violence in Poso, Central Sulawesi: Where people eat fish and fish eat people', Indonesia 72:45-79.

Arts, J.A.

1986 'Zending en bestuur op Midden-Celebes tussen 1890 en 1920; Van samenwerking naar confrontatie en eigen verantwoordelijkheid', in: J. van Goor (ed.), Imperialisme in de marge; De afronding van NederlandsIndië, pp. 85-121. Utrecht: HES. [Studies in Colonial and Non-European History 2.]

Bigalke, Terence William

1981 A social history of 'Tana Toraja' 1870-1965. [PhD thesis, University of Wisconsin, Madison.]

Coté, Joost

1996

'Colonising Central Sulawesi; The "ethical policy" and imperialist expansion, 1890-1910', Itinerario 20-3:87-107. 
Dijk, Cornelis van

1981 Rebellion under the banner of Islam; The Darul Islam in Indonesia. The Hague: Nijhoff. [KITLV, Verhandelingen 94.]

End, Th. van den

1985

De Gereformeerde Zendingsbond 1901-1961. Nederland-Tanah Toraja; Een bronnen-publicatie. N.p.: Raad voor de Zending der Nederlandse Hervormde Kerk, De Zending der Gereformeerde Kerken in Nederland, De Gereformeerde Zendingsbond in de Nederlandse Hervormde Kerk. [Project Kerkhistorische Uitgaven Indonesië.]

1991

'Een taalgeleerde onder de zendeling-leraren; Dr. H. van der Veen in Tana Toraja', in: Harry A. Poeze and Pim Schoorl (eds), Excursies in Celebes; Een bundel bijdragen bij het afscheid van J. Noorduyn als directeursecretaris van het Koninklijk Instituut voor Taal-, Land- en Volkenkunde, pp. 233-50. Leiden: KITLV Uitgeverij. [Verhandelingen 147.]

Errington, Shelly

1989 Meaning and power in a Southeast Asian Realm. Princeton NJ: Princeton University Press.

Harvey, Barbara S.

1977 Permesta: half a rebellion. Ithaca NY: Cornell University. [Monograph Series Publication 57.]

1989 Pemberontakan Kahar Muzakkar; Dari tradisi ke DI/TII. Jakarta: Grafitipers.

Henley, David

1993 'Nationalism and regionalism in colonial Indonesia; The case of Minahasa', Indonesia 55:91-112.

Kobong, Theodorus

1989 Evangelium und Tongkonan; Eine Untersuchung über die Begegnung zwischen christlicher Botschaft und der Kultur der Toraja. Hamburg: Verlag an der Lottbeck. [Perspektiven der Weltmission 7.]

Koolhof, Sirtjo

1999 'The "La Galigo"; A Bugis encyclopedia and its growth', Bijdragen tot de Taal-, Land-en Volkenkunde 155:362-87.

Li, T.M. 1999

'Marginality, power and production; Analysing upland transformations', in: T.M. Li (ed.), Transforming the Indonesian Uplands; Marginality, power, and production, pp. 1-37. Amsterdam: Harwood Academic Publishers.

2000 'Articulating indigenous identity in Indonesia; Resource politics and the tribal slot', Comparative Study of Society and History 42-1:149-79.

2001 'Relational histories and the production of difference on Sulawesi's upland frontier', Journal of Asian Studies 60-1:41-66.

Lijf, J.M. van

'Kentrekken en problemen van de geschiedenis der Sa'dan Toradjalanden', Indonesië 1:518-35.

1951

1952

‘Tana-Toradja 1905-1950', Indonesië 5:352-75.

'Tana-Toradja 1905-1950', Indonesië 6:254-77. 
Managing decentralisation

2003 Indonesia; Managing decentralisation and conflict in South Sulawesi. Jakarta/Brussels: International Crisis Group. [Asia Report 60.]

Morrell, E.

2002

'How many degrees of separation? Observations from South Sulawesi', Antropologi Indonesia 26:13-24.

2005 'Re-drawing Sulawesi's map; New provincial borders don't solve old problems', Inside Indonesia 82:18-9.

Nooy-Palm, Hetty

1979 The Sa'dan Toraja; A study of their social life and religion, Part I: Organization, symbols and beliefs. The Hague: Nijhoff. [KITLV, Verhandelingen 87].

Pakan, P.

1977

'Orang Toraja: identifikasi, klasifikasi dan lokasi', Berita Antropologi 9:2140.

Pelras, Christian

1996 The Bugis. Oxford: Blackwell. [The Peoples of South-East Asia and the Pacific.]

Peluso, Nancy Lee and Michael Watts

2001 'Violent environments', in: Nancy Lee Peluso and Michael Watts (eds), Violent environments, pp. 3-38. Ithaca NY: Cornell University Press.

Plaisier, B.

1993 Over bruggen en grenzen; De communicatie van het evangelie in het Torajagebied (1913-1942). Zoetermeer: Boekencentrum. [Mission 5.]

Reid, Anthony

1997

'Inside out; The colonial displacement of Sumatra's population', in: Peter Boomgaard, Freek Colombijn and David Henley (eds), Paper landscapes; Explorations in the environmental history in Indonesia, pp. 6189. Leiden: KITLV Press. [Verhandelingen 178.]

Roth, Dik

2002

2004 'From "Grooter Toradja" to "Toraja Raya"; Emergent ethnic identity,

'A national crisis in regional perspective; Some observations on Luwu District, South Sulawesi, Indonesia', in: Coen Holtzappel, Martijn Sanders and Milan Titus (eds), Riding a tiger; Dilemmas of integration and decentralization in Indonesia, pp. 181-210. Amsterdam: Rozenberg. expansionism and political struggle in Tana Toraja and Luwu, South Sulawesi, Indonesia', in: Martin Ramstedt (ed.), Hinduism in modern Indonesia; A minority religion between local, national, and global interests, pp. 160-83. London: RoutledgeCurzon.

forthcoming 'Many governors, no province; The struggle for a province in the Luwu-Tana Toraja area in South Sulawesi', in: Henk Schulte Nordholt and Gerry van Klinken (eds), Renegotiating boundaries; Local politics in post-Soeharto Indonesia. Leiden: KITLV Press.

Saathof, J.

1933

'Van het arbeidsveld; Met zendeling Pol op tournee', Alle den Volcke 27-4:53-7. 
Sanusi Dg. Mattata, Moh.

1967 Luwu dalam Revolusi; Mengandung perkembangan Keradjaan Luwu sedjak zaman bahari, sampai kepada perdjuangan pemuda-pemudanja diwaktu Revolusi Kemerdekaan Indonesia. Ujung Pandang: Yayasan Pembangunan Asrama, Ikatan Pelajar Mahasiswa Indonesia Luwu (IPMIL).

Sarira, J.A.

1975 Suatu survey mengenai Gereja Toraja Rantepao. Jakarta: Lembaga Penelitian dan Studi Dewan Gereja-Gereja di Indonesia. [Benih yang Tumbuh 6.]

Schiller, A. Arthur

1955 The formation of federal Indonesia, 1945-1949. The Hague/Bandung: Van Hoeve.

Schrauwers, Albert

1995 In whose image? Religious rationalization and the ethnic identity of the To Pamona of Central Sulawesi. [PhD thesis, University of Toronto.]

2000 'Pillars of faith; Religious rationalization in the Netherlands and Indonesia', Documentatieblad voor de Geschiedenis van de Nederlandse Zending en Overzeese Kerken 7-1:1-23.

Sejarah daerah

1984 Sejarah daerah Sulawesi Tengah. Jakarta: Proyek Inventarisasi dan Dokumentasi Kebudayaan Daerah, Departemen Pendidikan dan KeSmith Kipp, Rita budayaan.

1993 Dissociated identities; Ethnicity, religion, and class in an Indonesian society. Ann Arbor: Universty of Michigan Press.

Smith Kipp, Rita and Susan Rogers (eds)

1987 Indonesian religions in transition. Tucson: University of Arizona Press.

Tandjong, F.D.

1933 'Tentang kemadjoean lagi', Soelo 17.

Volkman, Toby Alice

1985

Feasts of honor; Ritual and change in the Toraja Highlands. Urbana: Uni-

Volkstelling

1931 versity of Illinois Press. [Illinois Studies in Anthropology 16.]

Volkstelling 1930; Voorloopige uitkomsten; Deel 2: Buitengervesten. Batavia: Landsdrukkerij. [Departement van Landbouw, Nijverheid en Handel.] 